\title{
EFEK PEMBERIAN BUNGKIL INTI SAWIT FERMENTASI DENGAN \\ LEVEL BERBEDA TERHADAP PERTAMBAHAN BOBOT BADAN \\ KAMBING CROSS BOER JANTAN LEPAS SAPIH
}

Besse Mahbuba We Tenri Gading, Najmah Ali, Niati Ningsih dan

Renaldhy Irsan

Universitas Sulawesi Barat, Indonesia

Politeknik Negeri Jember, Indonesia

E-mail: bessemahbuba@unsulbar.ac.id,najmaali@gmail.com, niantiningsih@gmail.com dan renaldhy@gmail.com

\section{Diterima:}

02 Januari 2022

Direvisi:

12 Januari 2022

Disetujui:

15 Januari 2022

\section{Abstrak}

Latar Belakang : Kambing Cross Boer merupakan kambing hasil persilangan antara kambing boerawa jantan dengan kambing Peranakan Etawa (PE) betina. Kelebihan kambing Boerawa terdapat pada tingkat pertumbuhan yang lebih cepat, dan daya tahan tubuh yang baik. Tujuan : Tujuan penelitian ini untuk mengetahui efek pemberian bungkil inti sawit fermentasi dengan level berbeda terhadap pertambahan bobot badan kambing Cross Boer jantan lepas sapih. Metode : Penelitian ini menggunakan 4 ekor kambing Cross Boer jantan lepas sapih berumur 11 bulan dengan bobot badan awal $17 \pm 3 \mathrm{~kg}$. Rancangan percobaan yang digunakan adalah Rancangan Bujur Sangkar Latin (RBL) dengan 4 perlakuan pemberian bungkil inti sawit dan 4 ulangan. Perlakuan yang diterapkan adalah sebagai berikut: $\mathrm{P} 0=$ pakan basal, $\mathrm{P} 1=$ pakan basal $+15 \%$ bungkil inti sawit fermentasi, $\mathrm{P} 2=$ pakan basal $+30 \%$ bungkil inti sawit fermentasi, $\mathrm{P} 3=$ pakan basal $+45 \%$ bungkil inti sawit fermentasi. Percobaan dilaksanakan selama 56 hari. Hasil : Hasil penelitian menunjukkan pemberian bungkil inti sawit fermentasi (P1, P2, P3) nyata menghasilkan konsumsi pakan yang lebih tinggi dibanding tanpa pemberian bungkil inti sawit fermentasi (P0), tetapi tidak berpengaruh nyata terhadap pertambahan beratbadan kambing. Kesimpulan : Berdasarkan hasil penelitian yang telah dilakukan maka dapat disimpulkan bahwa Pemberian bungkil inti sawit fermentasi dengan level berbeda berpengaruh nyata terhadap komsumsi pakan dan pertambahan bobot badan kambing Cross Boer jantan lepas sapih.

Kata kunci: Bungkil inti sawit, Bobot badan, Kambing Boer, Konsumsi pakan

Abstract
Background : The Cross Boer goat is the result of a cross
between a male Boerawa goat and a female Etawa Peranakan
(PE) goat. The advantages of Boerawa goats are in a faster
growth rate, and good immune system. Purpose : The purpose
of this study was to determine the effect of giving fermented palm
kernel cake with different levels on body weight gain of weaned
male Cross Boer goats. Method : This study used 4 weaned
male Cross Boer goats aged 11 months with an initial body


weight of $17 \pm 3 \mathrm{~kg}$. The experimental design used was the Latin Square Design (RBL) with 4 treatments of palm kernel cake and 4 replications. The treatments applied were as follows: $P 0=$ basal feed, $P 1=$ basal feed $+15 \%$ fermented palm kernel cake, $P 2=$ basal feed $+30 \%$ fermented palm kernel cake, P3 = basal feed $+45 \%$ fermented palm kernel cake. The experiment was carried out for 56 days. Results : The results showed that fermented palm kernel cake $(P 1, P 2, P 3)$ actually resulted in higher feed consumption than without fermented palm kernel cake (P0), but had no significant effect on goat body weight gain. Conclusion : Based on the results of the research that has been carried out, it can be concluded that the provision of fermented palm kernel cake with different levels has a significant effect on feed consumption and body weight gain of weaned male Cross Boer goats.

Keywords: Palm kernel cake, Body weight, Boer Goat, Feed consumption

\section{Pendahuluan}

Kambing Cross Boer merupakan kambing hasil persilangan antara kambing boerawa jantan dengan kambing Peranakan Etawa (PE) betina. Kelebihan kambing Boerawa terdapat pada tingkat pertumbuhan yang lebih cepat, dan daya tahan tubuh yang baik. Pemeliharaan dan perawatannya tidak begitu berbeda dengan kambing PE. Sehingga kambing tersebut lebih dipilih untuk dipelihara dan dikembangkan (Mahmilia \& Doloksaribu, 2010). Pemeliharaan Kambing Cross Boer tidak terlepas dari pemberian pakan yang berkualitas.

Pakan merupakan segala sesuatu yang dapat dimakan oleh ternak,dapat dicerna dan tidak membahayakan bagi tubuh siternak. Pemberian pakan dimaksudkan agar ternak ruminansia dapat memenuhi kebutuhan hidupnya sekaligus untuk pertumbuhan dan reproduksi. Cara yang dapat dilakukan untuk mencukupi bahan pakan di dalam negeri adalah dengan memanfaatkan bahan pakan lokal yang jumlahnya banyak tersedia, namun belum banyak dimanfaatkan sebagai pakan. Industri sawit di Indonesia cukup berkembang dan menjadi sumber pakan potensial yang belum banyak dimanfaatkan dalam industri peternakan terutama pemanfaatan limbah pertanian seperti hasil ikutan minyak sawit yaitu bungkil inti sawit (Sinurat, Mathius, \& Purwadaria, 2012).

Pertumbuhan perkebunan sawit di Indonesia sangat pesat, pada tahun 2013 produksi CPO (Crude Palm Oil) atau minyak sawit mentah di Indonesia meningkat sebesar $6.7 \%$ dari 22 juta ton menjadi 23.30 Juta ton (Pamurjadi \& Pharmasetiawan, 2014). Potensi kelapa sawit (Elaeis guinensis jacq) di dunia cukup besar, yaitu sebesar 4 milyar ton. Negara Indonesia, komoditas kelapa sawit cukup besar sehingga dapat mendukung potensi bungkil inti sawit yang merupakan hasil sampingan dari proses pembuatan minyak inti sawit. Bungkil inti sawit memiliki keterbatasan nutrisi terutama kandungan karbohidrat bukan pati (non-starch polysaccharides; NSPs) di dalam dinding selnya sehingga menyebabkan kandungan serat kasar yang variatif juga dan cenderung relatif tinggi. Usaha untuk meningkatkan ketersediaan nutrien didalam BIS dan menurunkan NSPs dapat dilakukan dengan proses fermentasi. Sebesar 5\% dari tandan buah segar sawit 3 menghasilkan inti sawit, inti sawit tersebut menghasilkan 45-46\%

Besse Mahbuba We Tenri Gading, Najmah Ali, Niati Ningsih dan Renaldhy 
minyak inti sawit dan bungkil inti sawit sebesar 45- 46\%. Selain itu, bungkil inti sawit juga mengandung Mannan Oligosakarida (MOS) yang dapat berperan sebagai prebiotik untuk menstimulasi perkembangan bakteri probiotik. Potensi ini dapat dimanfaatkan sebagai alternatif antibiotik di dalam pakan (Hanifa, 2017).

Bungkil inti sawit (BIS) adalah sumber protein bagi ternak ruminansia yang merupakan hasil ikutan atau limbah industri dari pengolahan kelapa sawit. Menurut Wijianto (2016) menyatakan bahwa, BIS mengandung protein yang cukup tinggi sebesar 21,51\% dan energi metabolis berkisar antara 1817-2654 Kkal/kg (Chanjula, Mesang, \& Pongprayoon, 2010). Kandungan protein BIS masih dapat ditingkatkan dengan cara pengolahan secara fermentasi (Mirnawati, Marlida, \& Kompiang, 2011).

Fermentasi adalah salah satu upaya untuk memperbaiki kualitas gizi, mengurangi, atau menghilangkan pengaruh negatif dari bahan pakan tertentu dengan menggunaan mikroorganisme (Parmesta, 2016). Fermentasi juga dapat meningkatkan nilai kecernaan pakan, menambah rasa dan aroma, meningkatkan kandungan vitamin dan mineral (Simanjuntak \& Tafsin, 2015). Pakan ternak ruminansia yang difermentasi dapat bermanfaat untuk memperbaiki sistem pencernaan ternak, meningkatkan produksi susu, meningkatkan nafsu makan ternak dan produksi daging ternak lebih berisi (Suhendro, Hidayat, \& Akbarillah, 2018).

Pengukuran bobot badan merupakan salah satu kriteria yang digunakan untuk mengukur pertumbuhan ternak. Pertambahan bobot badan ternak ruminansia sangat dipengaruhi oleh kualitas dan kuantitas pakan. Faktor yang memengaruhi pertambahan bobot badan yaitu total protein yang dikonsumsi, jenis ternak, umur, keadaan genetis lingkungan, kondisi setiap individu dan manajemen tata laksana (Alim \& Ternak, n.d. 2014). Berdasarkan uraian di atas maka peneliti tertarik untuk melakukan penelitian dengan menggunakan bungkil inti sawit fermentasi untuk meningkatkan pertambahan bobot badan (PBB) pada kambing Cross Boer jantan lepas sapih.

Tujuan penelitian ini adalah untuk mengetahui pengaruh pemberian bungkil inti sawit fermentasi dengan level berbeda terhadap pertambahan bobot badan kambing Cross Boer jantan lepas sapih, dan untuk mengetahui perlakuan terbaik pada pemberian bungkil inti sawit fermentasi dalam ransum pakan terhadap pertambahan bobot badan kambing Cross Boer jantan lepas sapih.

\section{Metode Penelitian}

Penelitian ini dilaksanakan mulai tanggal 18 Maret sampai dengan 14 Mei 2020, di Juragan Kambing Community (JK Community), Desa Tandassura kecamatan Limboro Kabupaten Polewali Mandar. Penelitian menggunakan sampel 4 ekor kambing Cross Boer lepas sapih yang dibagi dalam empat kelompok perlakuan. Umur kambing yang digunakan 11 bulan dengan rata-rata bobot badan awal antara $17 \pm 3 \mathrm{~kg}$. Pengukuran bobot badan pada ternak dilakukan dengan cara kambing ditimbang dengan menggunakan timbangan duduk, yaitu digendong oleh peneliti kemudian dilakukan penimbangan, hasil dari penimbangan tersebut dikurangi dengan bobot badan peneliti sehingga mendapatkan bobot badan kambing. Tahap berikutnya adalah ternak dimasukkan kedalam kandang yang telah di siapkan. Kandang yang digunakan dalam penelitian ini adalah kandang tunggal berbentuk panggung yang disekat dalam sebanyak 4 petak. Ukuran kandang individual untuk setiap petak adalah $75 \times 75 \times 75 \mathrm{~cm}$. Selama penelitian berlangsung, setiap kambing diberikan pakan perlakuan dan pakan basal (Afrianda, 2019). Bungkil inti sawit dibuat dengan tata cara tahapan pembuatan bungkil inti sawit, diperoleh dari perusahaan pabrik kelapa sawit kemudian diayak atau disaring agar menjadi halus lalu difermentasi. Pemberian bungkil inti sawit diberi tersendiri sesuai perlakuan dengan proporsi bungkil inti sawit sebanyak $0 \% ; 15 \% ; 30 \% ; 45 \%$. 
Efek Pemberian Bungkil Inti Sawit Fermentasi dengan

Level Berbeda Terhadap Pertambahan Bobot Badan

Kambing Cross Boer Jantan Lepas Sapih

Rancangan yang digunakan dalam penelitian ini adalah Bujur Sangkar Latin (BSL). Rancangan BSL terdiri dari 4 perlakuan dan 4 ulangan. Setiap ulangan 
mendapatkan beberapa perlakuan dengan persentase bungkil inti sawit yang berbeda, dengan perlakuan pada Tabel 1. sebagai berikut:

Tabel 1.

Kelompok Perlakuan

\begin{tabular}{llccc}
\hline Ulangan & & \multicolumn{3}{c}{ Kelompok Perlakuan } \\
\hline I & P0.1 & P1.1 & P2.1 & P3.1 \\
II & P0.2 & P1.2 & P2.2 & P3.2 \\
III & P0.3 & P1.3 & P2.3 & P3.3 \\
IV & P0.4 & P1.4 & P2.4 & P3.4 \\
\hline
\end{tabular}

Keterangan: $\mathrm{P} 0=$ pakan basal

$\mathrm{P} 1=$ pakan basal $+15 \%$ bungkil inti sawit fermentasi

$\mathrm{P} 2=$ pakan basal $+30 \%$ bungkil inti sawit fermentasi

$\mathrm{P} 3=$ pakan basal $+45 \%$ bungkil inti sawit fermentasi

Pakan basal terdiri dari dedak padi, jagung giling, molasses, garam, kulit kacang, mineral dan hijauan.

$\mathbf{Y i j}=\boldsymbol{\mu}+\boldsymbol{\alpha} \mathbf{i}+\mathbf{i j}+\sum \mathbf{i j}$

Dimana:

Yij = Respon atau nilai pengamatan dari perlakuan ke-i dan ulangan ke

$\mu=$ Nilai tenga

$\alpha \mathrm{i}=$ Pengaruh blok ke- $\mathrm{i}$

ij = Pengaruh blok ke-j

$\sum \mathrm{ij}=$ Pengaruh galat (Experimental error) perlakuan ke-I ulangan ke-j.

\section{Hasil dan Pembahasan}

\section{Konsumsi Pakan}

Konsumsi pakan kambing dari hasil penelitian pada kambing Cross Boer berkisar antara 1765 gram - 2250 gram. Nilai rata-rata konsumsi pakan dapat dilihat pada tabel 2 dan tabel 3.

Tabel 2.

Rata-rata Komsumsi Pakan selama perlakuan (gram)

\begin{tabular}{ccccc}
\hline \multirow{2}{*}{ Ulangan } & \multicolumn{4}{c}{ Perlakuan } \\
\cline { 2 - 5 } & P0 & P1 & P2 & P3 \\
\hline 1 & 1895 & 1860 & 1902 & 1787 \\
2 & 2010 & 1772 & 1848 & 1786 \\
3 & 2087 & 1765 & 2131 & 1943 \\
4 & 2193 & 2212 & 2250 & 2227 \\
\hline
\end{tabular}


Efek Pemberian Bungkil Inti Sawit Fe

Level Berbeda Terhadap Pertambaha

Kambing Cross Boer Jantan Lepas Sapih

Tabel 3.

Rata-rata konsumsi pakan kambing cross boer Jantan lepas sapih

\begin{tabular}{ccccc}
\hline \multirow{2}{*}{ Parameter } & \multicolumn{4}{c}{ Perlakuan } \\
\cline { 2 - 5 } & P0 & P1 & P2 & P3 \\
\hline $\begin{array}{c}\text { Konsumsi pakan } \\
\text { (kg/ekor/hari) }\end{array}$ & $2,05^{\mathrm{a}}$ & $1,90^{\mathrm{c}}$ & $2,03^{\mathrm{ab}}$ & $1,94^{\mathrm{c}}$ \\
\hline
\end{tabular}

Keterangan: Superskrip yang berbeda pada kolom yang sama menunjukkkan perbedaan yang nyata $(\mathrm{P}<0,05)$.

Tabel 3. menunjukkan bahwa, kelompok perlakuan P0 dan P2 tidak berbeda nyata $(\mathrm{P}>0,05)$ sedangkan $\mathrm{P} 0, \mathrm{P} 1$, dan $\mathrm{P} 3$ berbeda nyata $(\mathrm{P}<0,05)$. Nilai rata-rata konsumsi pakan bungkil inti sawit fermentasi pada kambing Cross Boer jantan lepas sapih dengan konsentrasi berkisar antara $1,90 \mathrm{~kg}-2,05 \mathrm{~kg} / \mathrm{ekor} / \mathrm{hari}$. Hal tersebut disebabkan karena pakan yang diberikan pada kelompok perlakuan dan kontrol memiliki tingkat palatabilitas yang sama sehingga konsumsi pakan juga tidak terlalu berbeda. Konsumsi pakan dipengaruhi oleh palatabilitas pakan yang dikonsumsi. Nilai konsumsi ternak dipengaruhi oleh palatabilitas dan palatabilitas dipengaruhi oleh parameter fisik dan kimiawi yang diransang oleh penglihatan, penciuman dan rasa dari ternak (Soeharsono \& Diwyanto, 2010). Palatabilitas pakan merupakan salah satu faktor yang mempengaruhi jumlah konsumsi dan kemampuan ternak untuk mengkonsumsi bahan kering yang terkandung dalam pakan, selain itu tinggi rendahnya konsumsi pakan pada ternak ruminansia sangat dipengaruhi oleh faktor lingkungan dan kondisi ternak (Gading, Agus, Irawan, \& Panjono, 2020).

\section{Pertambahan Bobot Badan}

Hasil penelitian tentang pengaruh pemberian bungkil inti sawit dengan level berbeda terhadap pertambahan bobot badan (PBB) pada kambing cross boer jantan lepas sapih diperoleh hasil pada Tabel 5. Hasil pertambahan bobot badan (PBB) kambing Cross Boer jantan lepas sapih dengan pemberian bungkil inti sawit fermentasi dengan level $15 \% ; 30 \% ; 45 \%$ berkisar antara $0.20-0.58 \mathrm{Kg} /$ ekor/hari. Pemberian bungkil inti sawit dengan level berbeda terhadap pertambahan berat badan kambing Cross Boer jantan lepas sapih pada perlakuan $\mathrm{P} 0, \mathrm{P} 1$, dan $\mathrm{P} 2$ tidak berpengaruh nyata $(\mathrm{P}>0,05)$ sedangkan kelompok perlakuan $\mathrm{P} 0$ dan $\mathrm{P} 3$ berpengaruh nyata $(\mathrm{P}<0,05)$ terhadap pertambahan bobot badan (PBB). Konsumsi pakan tergantung pada jumlah bahan kering pakan yang dikonsumsi ternak dan kandungan nutrisi pakan yang diberikan (Adriani, Latif, Fachri, \& Sulaksana, 2014). Tingkat konsumsi pakan juga dipengaruhi oleh beberapa faktor yaitu faktor ternak, (bobot badan dan umur), tingkat kecernaan pakan, kualitas pakan dan palatabilitas.

Tabel 4.

Rata-rata Jumlah Pertambahan Bobot Badan (PBB) Kambing Cross Boer Jantan Lepas Sapih pada Setiap Kelompok Perlakuan

\begin{tabular}{cccccc}
\hline \multirow{2}{*}{ Keterangan } & \multirow{2}{*}{ Ulangan } & \multicolumn{4}{c}{ Perlakuan } \\
\cline { 3 - 6 } & 1 & P0 & P1 & P2 & P3 \\
\hline \multirow{3}{*}{ Parameter } & 2 & 0.20 & 0,40 & 0,00 & 1,00 \\
& 3 & 0.30 & 0,00 & 0,10 & 0,90 \\
& 0.60 & 0,20 & 1,00 & 0,00 \\
\hline
\end{tabular}

Besse Mahbuba We Tenri Gading, Najmah Ali, Niati Ningsih dan Renaldhy 


\begin{tabular}{cccccc}
\hline $\begin{array}{c}\text { Pertambahan Bobot Badan } \\
(\mathrm{Kg})\end{array}$ & 4 & 0.00 & 0,20 & $-0,20$ & 0,40 \\
\hline & $0,20^{\mathrm{a}}$ & $0,20^{\mathrm{ab}}$ & $0,23^{\mathrm{ab}}$ & $0,58^{\mathrm{c}}$ \\
\hline
\end{tabular}

Keterangan : Superskrip yang berbeda pada kolom yang sama menunjukkkan perbedaan yang nyata $(\mathrm{P}<0,05)$.

Penelitian sebelumnya yang dilakukan oleh Suhendro, dkk., (2018) pada kambing Nubian dara dengan menggunakan bungkil inti sawit menunjukkan bahwa pakan konsentrat berbahan bungkil inti sawit belum disukai ternak sehingga tidak dikonsumsi dalam jumlah banyak. Pemberian bungkil inti sawit fermentasi tidak memberikan pengaruh yang nyata terhadap pertambahan bobot badan kambing Cross Boer. Pertambahan bobot badan adalah kemampuan ternak untuk dapat mengubah zat nutrisi dari pakan yang diberikan untuk diubah menjadi produk ternak seperti daging. Pertumbuhan juga dapat diukur dari berat hidup, komposisi tubuh ternak termasuk perubahan organ dan jaringan tubuh ternak. Pakan yang cukup mengandung protein dan memiliki struktur yang lebih halus akan lebih cepat dicerna oleh mikroba di dalam rumen sehingga terjadi peningkatan laju pencernaan makanan di dalam rumen dan dapat meningkatkan jumlah konsumsi pakan sehingga berdampak positif terhadap pertumbuhan. Faktor-faktor yang mempengaruhi pertambahan bobot badan dantaranya perbedaan konsumsi pakan pada setiap kelompok perlakuan, kualitas dan kuantitas pakan yang diberikan, faktor genetik (keturunan), dan faktor lingkungan.

Pertambahan bobot badan harian kambing cross boer jantan lepas sapih ada yang tidak berpengaruh nyata dan berpengaruh nyata. Hal ini disebabkan karena konsumsi pakan kambing cross boer jantan lepas sapih juga tidak berpengaruh nyata dan juga memberikan pengaruh yang nyata, serta kambing cross boer jantan lepas sapih yang belum dewasa kelamin, sehingga hormon reproduksi yang mempengaruhi pertumbuhan belum optimal dan konsumsi pakan yang tidak teratur. Hormon androgen belum optimal, karena ternak belum mencapai dewasa kelamin (Melvina, 2017). Selain itu kambing cross boer jantan lepas sapih mengkonsumsi nutrien pakan yang tidak berpengaruh nyata, yang menyebabkan pertumbuhan juga cenderung sama. Sesuai dengan hasil penelitian Susanto (2008) yang menyatakan bahwa PBBH ternak yang tidak berbeda disebabkan karena konsumsi pakan dan kandungan nutrien pada kedua jenis kelamin relatif sama.

\section{Kesimpulan}

Berdasarkan hasil penelitian yang telah dilakukan maka dapat disimpulkan bahwa Pemberian bungkil inti sawit fermentasi dengan level berbeda berpengaruh nyata terhadap komsumsi pakan dan pertambahan bobot badan kambing Cross Boer jantan lepas sapih. Saran untuk penelitian berikutnya adalah perlu dilakukan penelitan lebih lanjut untuk melihat tingkat kecernaan kambing Cross Boer dengan pemberian bungkil inti sawit fermentasi.

\section{Bibliografi.}

Adriani, A., Latif, A., Fachri, S., \& Sulaksana, I. (2014). Peningkatan produksi dan kualitas susu kambing Peranakan Etawah sebagai respon perbaikan kualitas pakan. Jurnal Ilmiah Ilmu-Ilmu Peternakan, 17(1), 15-21.

Afrianda, Randi. (2019). Pemberian Pellet Berbahan Tambahan Tepung Daun Pepaya (Carica Papaya. L) Dengan Level Yang Berbeda Terhadap Bobot Akhir, Persentase Karkas Dan Lemak Abdominal Ayam Pedaging. Riau: Universitas Islam Negeri Sultan Syarif Kasim Riau.

Alim, Herlina, \& Ternak, Jurusan Produksi. (N.D.). Pertambahan Bobot Badan Kambing 
Efek Pemberian Bungkil Inti Sawit Fermentasi dengan

Level Berbeda Terhadap Pertambahan Bobot Badan

Kambing Cross Boer Jantan Lepas Sapih

Marica Jantan Dengan Pemberian Pakan Komplit Pada Taraf Protein. 
Chanjula, Pin, Mesang, Areewan, \& Pongprayoon, Sahutaya. (2010). Effects of dietary inclusion of palm kernel cake on nutrient utilization, rumen fermentation characteristics and microbial populations of goats fed Paspalum plicatulum haybased diet. Sonklanakarin Journal of Science and Technology, 32(6), 527.

Gading, BMWT, Agus, A., Irawan, A., \& Panjono, P. (2020). Growth performance, hematological and mineral profile of post-weaning calves as influenced by inclusion of pelleted-concentrate supplement containing essential oils and probiotics. Iranian Journal of Applied Animal Science, 10(3), 461-468.

Hanifa, Laily. (2017). Pengaruh Penggunaan Bungkil Inti Sawit Terhadap Efisiensi Penggunaan Protein Pada Puyuh (Coturnix Coturnix Japonica) Betina Fase Grower. Jambi: Universitas Jambi.

Mahmilia, Fera, \& Doloksaribu, Meruwald. (2010). Keunggulan relatif anak hasil persilangan antara kambing Boer dengan Kacang pada periode prasapih. JITV, 15(2), 124-130.

Melvina, Shellyn. (2017). Ukuran Tubuh dan Pertumbuhan Pasca Sapih Sapi Jabres Jantan dan Betina di Kecamatan Bantarkawung, Brebes, Jawa Tengah. Yogyakarta: Universitas Gadjah Mada.

Mirnawati, Y. Rizal, Marlida, Yetti, \& Kompiang, I. Putu. (2011). Evaluation of palm kernel cake fermented by Aspergillus niger as substitute for soybean meal protein in the diet of broiler. International Journal of Poultry Science, 10(7), 537-541.

Pamurjadi, Andy, \& Pharmasetiawan, Bambang. (2014). Analisis dan Rancangan Manajemen Service Desk di Instansi Pemerintah (Studi Kasus: Badan Litbang Pertanian). Jurnal Iptekkom (Jurnal Ilmu Pengetahuan \& Teknologi Informasi), 16(1), 69-88.

Parmesta, Setyo. (2016). Nilai Energi Metabolis dan Retensi Nitrogen Ransum yang Mengandung Kedelai (Glycine max) Hasil Fermentasi pada Ayam Broiler. Students E-Journal, 5(1).

Simanjuntak, Srimastuti, \& Tafsin, Ma'ruf. (2015). Fermentasi Hasil Samping Industri Dan Perkebunan Kelapa Sawit Dengan Probiotik Lokal Terhadap Performans Domba: Fermented Oil Palm Industry and Plantation by Product by Local Probiotics on Performances of Sheep. Jurnal Peternakan Integratif, 4(1), 83-95.

Sinurat, A. P., Mathius, I. W., \& Purwadaria, T. (2012). Pengolahan dan pemanfaatan hasil samping industri sawit sebagai bahan pakan. Balitbang Pertanian, Jakarta.

Soeharsono, R. A. SAPTATI, \& Diwyanto, K. (2010). Penggemukan sapi lokal hasil inseminasi buatan dan sapi bakalan impor dengan menggunakan bahan pakan lokal. Seminar Nasional Teknologi Peternakan Dan Veteriner.

Suhendro, Suhendro, Hidayat, Hidayat, \& Akbarillah, T. (2018). Pengaruh Penggunaan Bungkil Inti Sawit, Minyak Sawit, dan Bungkil Inti Sawit Fermentasi Pengganti Ampas Tahu dalam Ransum terhadap Pertumbuhan Kambing Nubian Dara. Jurnal Sain Peternakan Indonesia, 13(1), 55-62.

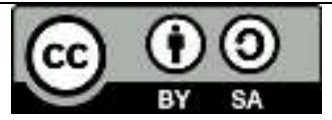

This work is licensed under a Creative Commons Attribution-ShareAlike 4.0 International License. 